University of Nebraska - Lincoln

DigitalCommons@University of Nebraska - Lincoln

Susceptibility of Tribolium castaneum (Coleoptera:

Tenebrionidae) and Trogoderma inclusum (Coleoptera: Dermestidae) to cold temperatures

\author{
Frank H. Arthur \\ K. L. Hartzer \\ USDA-ARS \\ James E. Throne \\ USDA-ARS, Manhattan, KS, james.throne@ars.usda.gov \\ P. W. Flinn \\ Retired
}

U.S. Grain Marketing and Production Research Center, frank.arthur@ars.usda.gov

Follow this and additional works at: https://digitalcommons.unl.edu/usdaarsfacpub

Arthur, Frank H.; Hartzer, K. L.; Throne, James E.; and Flinn, P. W., "Susceptibility of Tribolium castaneum (Coleoptera: Tenebrionidae) and Trogoderma inclusum (Coleoptera: Dermestidae) to cold temperatures" (2015). Publications from USDA-ARS / UNL Faculty. 2055.

https://digitalcommons.unl.edu/usdaarsfacpub/2055

This Article is brought to you for free and open access by the U.S. Department of Agriculture: Agricultural Research Service, Lincoln, Nebraska at DigitalCommons@University of Nebraska - Lincoln. It has been accepted for inclusion in Publications from USDA-ARS / UNL Faculty by an authorized administrator of DigitalCommons@University of Nebraska - Lincoln. 


\title{
Susceptibility of Tribolium castaneum (Coleoptera: Tenebrionidae) and Trogoderma inclusum (Coleoptera: Dermestidae) to cold temperatures
}

\author{
F.H. Arthur ${ }^{\text {a, }}{ }^{*}$, K.L. Hartzer ${ }^{\text {a }}$, J.E. Throne ${ }^{\mathrm{b}}$, P.W. Flinn ${ }^{\mathrm{a}, 1}$ \\ a USDA, Agricultural Research Service, Center for Grain and Animal Health Research, 1515 College Avenue, Manhattan, KS, 66502, USA \\ ${ }^{\mathrm{b}}$ USDA, Agricultural Research Service, San Joaquin Valley Agricultural Sciences Center, 9611 South Riverbend Avenue, Parlier, CA, 93648, USA
}

\section{A R T I C L E I N F O}

\section{Article history:}

Received 18 March 2015

Received in revised form

6 July 2015

Accepted 18 July 2015

Available online 28 August 2015

\section{Keywords:}

Tribolium castaneum

Trogoderma inclusum

Cold

Susceptibility

\begin{abstract}
A B S T R A C T
Studies were conducted by exposing different life stages of Tribolium castaneum (Herbst), the red flour beetle, and Trogoderma inclusum (LeConte), the larger cabinet beetle, for different time intervals to $-18{ }^{\circ} \mathrm{C}$. Assessments were made of direct mortality to eggs, larvae, and adults, and eventual adult emergence of immatures. Data were described by non-linear equations. The eggs and larvae were the most tolerant life stage of $T$. castaneum. Eight hours of exposure were required for $100 \%$ kill of 3-4-dayold eggs and $0-10$ - and 11-21-day-old larvae, but only $4,0.5$, and $0.5 \mathrm{~h}$ respectively were required to completely inhibit adult emergence. For $T$. inclusum, the most tolerant life stage was 15-28-day-old larvae; 64 and $16 \mathrm{~h}$ respectively were required for complete mortality and inhibition of adult emergence. Results indicate that $T$. inclusum was the more tolerant species, and specific treatment protocols may be required for different stored product beetle species when using $-18^{\circ} \mathrm{C}$ as a disinfestation strategy.
\end{abstract}

๑) 2015 Published by Elsevier Ltd.

\section{Introduction}

Tribolium castaneum (Herbst), the red flour beetle, is a cosmopolitan insect pest of stored products. It can be found in milling and processing facilities, in bulk commodities, and in bulk grains. Developmental time is dependent on food source, temperature, and r.h. (Howe, 1965). In general, normal egg to adult development on flour takes 6 weeks at $27{ }^{\circ} \mathrm{C}$, and the adult can live for months or even for a couple of years in extreme cases (White, 1987; Howe, 1962). The life cycle is typical of many stored grain beetles, with the adult capable of producing eggs for most of their lives (Howe, 1962).

Dermestid beetles can also infest many different stored products, but they are primarily found infesting processed and packaged foods, and they are usually short-lived as adults (Rees, 2004). Members of the family Dermestidae can be found throughout much of the temperate regions of the world (Rees, 2004), including the United States (US) (Partida and Strong, 1970). In contrast to flour beetles, dermestid adults typically live only for 2-3 weeks on average, depending on temperature and diet (Loschiavo, 1960, 1967; Partida and Strong, 1970). Larvae of many dermestids can

\footnotetext{
* Corresponding author.

E-mail address: frank.arthur@ars.usda.gov (F.H. Arthur).

1 Retired.
}

enter diapause before reaching the adult stage (Partida and Strong, 1975; Wright et al., 2002). Trogoderma inclusum (LeConte), the larger cabinet beetle, is a dermestid beetle that can infest bulk grains, milled products, and structures in the US (Vick et al., 1973; Partida and Strong, 1970; Hagstrum, 1987; Mullen and Arbogast, 1988). It is a diverse feeder and can be an important industrial pest because of its wide host range and ability of the larvae to persist on a limited food source (Partida and Strong, 1975). This species is native to the US and/or the British Isles and is similar in habits to other dermestid beetles (Beal, 1954), and it can co-exist with other dermestids and mate within the genus but does not produce viable hybrids (Vick, 1973; Vick et al., 1973).

Life stages of $T$. castaneum are differentially susceptible to extreme high temperatures, with young larvae being the most tolerant life stage (Mahroof et al., 2003a,b). Similar studies by Wright et al. (2002) with Trogoderma variabile (Ballion), the warehouse beetle, have shown that full-grown larvae were the most heat-tolerant life stage to high temperatures. The use of cold temperatures has also been advocated as a control strategy (Fields and White, 2002), but most recent studies have been conducted using extreme heat to kill insects rather than extreme cold. Therefore, the objectives of this study were to: 1 ) determine the time required to kill different life stages of $T$. castaneum and $T$. inclusum at a target temperature of $-18{ }^{\circ} \mathrm{C}$, and 2) compare susceptibility of the two species. The specific target temperature 
threshold was selected because it is a typical setting for commercial freezing units used by the milling and processing industries in the US (Johnson and Valero, 2003).

\section{Materials and methods}

This study was conducted at the USDA-ARS Center for Grain and Animal Health Research, Manhattan, KS. The T. castaneum strain used for the study was originally collected from a Midwestern food storage facility in 2005, and the colony had been maintained on a diet of 95\% all-purpose wheat flour and 5\% Brewer's yeast. The $T$. inclusum strain was collected from a rice mill in eastern Arkansas in 2012 and had been maintained on a diet of protein shake powder consisting of $37 \%$ protein, $37 \%$ carbohydrates, $13 \%$ fiber, $5 \%$ fat, all by weight, along with various other elements. T. castaneum was reared in 16:8 (L:D) inside an incubator set at $27.5{ }^{\circ} \mathrm{C}$ and $65 \%$ r.h. The $T$. inclusum colonies were reared in a different incubator set at $30{ }^{\circ} \mathrm{C}$ under the same light and r.h. conditions. Both species were reared in $0.95 \mathrm{~L}$ glass jars. The freezer used in the study was a Percival upright model I36NLXC9 purchased in 2011 (Percival-Scientific, Perry IA, USA). The freezer was modified by the manufacturer to contain a dual unit cooling system to minimize temperature spikes during the time when the cooler was defrosting. Testing procedures will be described separately for each species.

\subsection{T. castaneum}

The experimental unit for all life stages of T. castaneum was a 7dram plastic vial (50 $\mathrm{mm}$ in height by $25 \mathrm{~mm}$ diameter). Preliminary tests were done to define approximate exposure intervals at the target temperature that would prevent eggs from advancing past the initial larval stages, prevent larvae and/or pupae from reaching the adult stage, or cause death of adults within a week after exposure.

Exposure studies were done by exposing 25 individuals that were in one of the following life stages to $-18{ }^{\circ} \mathrm{C}$ for $15,30,60,90$, $120,240,360$, and $480 \mathrm{~min}$ (8 time intervals): 0-2 day-old eggs, 3-4 day-old eggs, 0-10-day-old larvae (young larvae), 11-21-dayold larvae (old larvae), 0-4-day-old pupae, 5-8-day-old pupae, 0-7-day-old adults, and 21-28-day-old adults (8 life stages). Eggs were collected by allowing 100-150 mixed-age adults from the primary colony jars to oviposit on about $200 \mathrm{~g}$ of the same standard rearing medium in each of two $118 \mathrm{ml}$ glass jars for two days. The adults were removed, and eggs were then collected by sifting the flour through a US \#60 standard testing sieve (openings of $0.25 \mathrm{~mm}$ ), examining the flour under a stereo microscope, and removing individual eggs using a low-airflow aspirator. Not enough eggs could be collected on one day to set up all treatments, so this process was repeated by establishing two sets of 118-ml jars each time until all replications were complete. This resulted in multiple sets of two 118-ml jars that were then maintained in the same chamber as the primary colony, and larvae, pupae, and adults were collected with forceps as the original progeny matured.

The 25 individuals of each life stage were placed in a vial with no food material to avoid insulation effects, set inside the freezer maintained at the target of $-18{ }^{\circ} \mathrm{C}$, and exposed at the eight time intervals. We exposed the insects without food because, in this study, we wanted to determine how long it took to kill the insects once they reached the target temperature. The time required to reach the target temperature would depend on type and quantity of food. Thus, our results would be applicable to any type or quantity of food infested by these insects. Groups of 25 individuals of each specific life stage were also prepared as untreated controls. Approximately $200 \mathrm{mg}$ of the rearing diet was added to each control vial, which were then immediately placed inside an environmental chamber set at $27.5{ }^{\circ} \mathrm{C}$ and $65 \%$ r. h. Upon completion of each exposure interval, the individual vials were removed from the freezer and allowed to warm for about $1 \mathrm{~h}$ to room temperature (about $25^{\circ} \mathrm{C}$ ) to eliminate condensation and moisture from the vials. Approximately $200 \mathrm{mg}$ of the rearing diet was then added to each vial as described above for the untreated controls, and the vials were placed in the same environmental chamber as the controls.

Vials containing immature life stages were held for one week, and then mortality was assessed. These vials were then checked weekly for adult emergence. Mortality of adults was assessed after one week and after 21 days. After the initial survival assessment at one week, an additional $200 \mathrm{mg}$ of diet was added to each vial containing an immature stage, in order to ensure sufficient food for normal development to the adult stage. Each group of vials was replicated six times.

Data were analyzed using the General Linear Models Procedure of the Statistical Analysis System (SAS Institute, version 9.2, Cary, NC, USA) to determine exposure time required for complete mortality after 1 week, which is defined as the direct death of immatures or failure of immatures to survive to the next life stage, or for direct mortality of adults. The exposure time required to prevent immatures from emerging as adults was also determined. Data for individual life stages were plotted with time as the independent variable and mortality as the dependent variable, and curves were fit to the data using Table Curve software (Table Curve 2D Version 5.1, Systat Software, San Jose, CA, USA).

\subsection{T. inclusum}

Exposure studies were done by exposing 25 individuals that were in one of the following life stages: 0-2 day-old eggs, 3-4 dayold eggs, 5-6 day-old eggs, 0-14-day-old larvae (young larvae), 15-28-day-old larvae (old larvae), pupae, 0-4-day-old adults, and 5-8-day-old adults (8 life stages). Eggs were collected as previously described for $T$. castaneum by allowing 100-150 mixed-age adults from the primary colony jars to oviposit on about $200 \mathrm{mg}$ of the same standard flour rearing medium used for T. castaneum in each of two $118 \mathrm{ml}$ glass jars for two days. The adults were removed, and eggs were then collected by sifting the flour through a US \#70 standard testing sieve (openings of $0.25 \mathrm{~mm}$ ), examining the flour under a stereo microscope, and removing individual eggs using a low-airflow aspirator. However, after eggs were collected, they were transferred to $118-\mathrm{ml}$ jars containing $200 \mathrm{~g}$ of the protein shake rearing medium. This process was repeated continuously, as described for T. castaneum, by establishing two sets of 118-ml jars each time until all replications were complete. These multiple sets of two 118-ml jars containing the protein shake rearing medium were maintained in the $30^{\circ} \mathrm{C}$ chamber described above, and larvae, pupae, and adults were collected with forceps as the original progeny matured.

Preliminary studies showed that longer exposure times were required to kill eggs of $T$. inclusum compared to $T$. castaneum, therefore assessment times are described in hours rather than minutes. The 25 individuals of each life stage were placed in a vial with no food material, again to avoid insulation effects, set inside the freezer maintained at the target of $-18{ }^{\circ} \mathrm{C}$, and exposed at various time intervals as follows: eggs $2,4,6,8,10,12,14$, and $16 \mathrm{~h}$; 15-28 day-old-larvae, $8,16,24,32,40,48,56,64$, and $72 \mathrm{~h}$; and adults $4,8,12,16,20$, and $24 \mathrm{~h}$. Preliminary tests showed that $0-14$ day-old young larvae and pupae were the most susceptible life stages, therefore the exposure times used for these stages were the same intervals as those used for T. castaneum, $0.25,0.5,0.75,1,1.5,2$, 4,6 , and 8 h. Groups of 25 individuals of each specific life stage were also prepared as untreated controls. Approximately $200 \mathrm{mg}$ of the 
protein shake rearing diet was added to each control vial, which were then immediately placed inside an environmental chamber set at $30{ }^{\circ} \mathrm{C}$ and $65 \% \mathrm{r}$. h. Upon completion of each exposure interval, the individual vials were removed from the freezer and allowed to warm for about $1 \mathrm{~h}$ to room temperature (about $25^{\circ} \mathrm{C}$ ) to eliminate condensation and moisture from the vials. Approximately $200 \mathrm{mg}$ of the rearing diet was then added to each vial, as described for T. castaneum, and the vials were placed in the same environmental chamber as the controls. Assessments were made weekly as for $T$. castaneum, except that mortality counts for adults were made at 2 days post-exposure. After this time, mortality began occurring in unexposed controls as the adult stage is relatively short for this beetle species. Data were analyzed using the SAS Procedures and Table Curve Software as described above for $T$. castaneum.

\section{Results}

\subsection{T. castaneum}

The main effects life stage and exposure time, and their interaction, were significant at $P<0.01$ for both the initial survival after one week $(\mathrm{F}=194.6, \mathrm{df}=7,390 ; \mathrm{F}=553.4$, df $=9$, 390; and
$\mathrm{F}=18.5, \mathrm{df}=61,390$, respectively), and also for eventual adult emergence of immatures $(\mathrm{F}=68.4, \mathrm{df}=7,390 ; \mathrm{F}=2377.3, \mathrm{df}=9$, 390; and $\mathrm{F}=56.8, \mathrm{df}=61,290$, respectively). Data for individual life stages were analyzed by fitting curves to the data (Table 1 ). Initial survival and adult emergence decreased exponentially as the exposure time increased. Significant differences within a particular life stage and exposure interval were also determined ( $t$-test, $P<0.05$ ). In some cases curves could not be fit to the data because survivorship was essentially 0 after 15 min of exposure to $-18{ }^{\circ} \mathrm{C}$.

Survival of $0-2$-day-old eggs exposed to $-18^{\circ} \mathrm{C}$, as assessed by percentage of egg hatch, decreased to near 0 as exposure time increased from 15 to $120 \mathrm{~min}$ (Fig. 1A). Scattered hatch occurred beyond $120 \mathrm{~min}$. The 3-4-day-old eggs were slightly more tolerant. Survival was usually greater compared to the 0-2-day-old eggs at the shorter exposure intervals, with scattered survival beyond $120 \mathrm{~min}$ (Fig. 1B). However, most of the hatched larvae from the 0-2-day-old eggs eventually died before reaching the adult stage, as there was little eventual adult emergence beyond the 90min exposures (Fig. 1C). Adult emergence was generally higher in the 3-4-day-old eggs exposed for $15-60 \mathrm{~min}$ to $-18{ }^{\circ} \mathrm{C}$ compared to the 0-2-day-old eggs (Fig. 1D). No 0-10-day-old larvae survived beyond $15 \mathrm{~min}$ of exposure to $-18^{\circ} \mathrm{C}$ (Fig. 2A), whereas survival of 11-21-day-old larvae did occur out to the 360-min exposures

Table 1

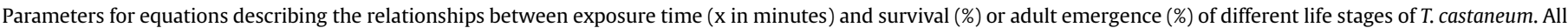

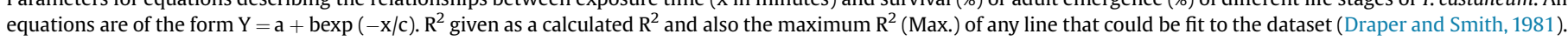
Equations could not be determined for life stages not listed because survival was at or near 0 by the 30-min exposure interval.

\begin{tabular}{|c|c|c|c|c|c|}
\hline Life stage & $\mathrm{a}$ & $\mathrm{b}$ & c & $\mathrm{R}^{2}$ & Max. $\mathrm{R}^{2}$ \\
\hline \multicolumn{6}{|c|}{ Initial survival after one week } \\
\hline 0-2-day-old egg & $2.97 \pm 2.4$ & $84.72 \pm 4.5$ & $29.92 \pm 3.5$ & 0.85 & 0.86 \\
\hline 3-4-day-old egg & $0.64 \pm 2.4$ & $85.88 \pm 3.3$ & $84.20 \pm 8.0$ & 0.92 & 0.93 \\
\hline 11-21-day-old larvae & 0 & $102.8 \pm 4.4$ & $26.87 \pm 2.21$ & 0.89 & 0.94 \\
\hline \multicolumn{6}{|l|}{ Adult emergence } \\
\hline 0-2-day-old egg & 0 & $76.0 \pm 3.5$ & $17.31 \pm 1.7$ & 0.87 & 0.87 \\
\hline 3-4-day-old egg & $-4.86 \pm 3.1$ & $79.23 \pm 3.9$ & $47.30 \pm 5.6$ & 0.90 & 0.93 \\
\hline
\end{tabular}
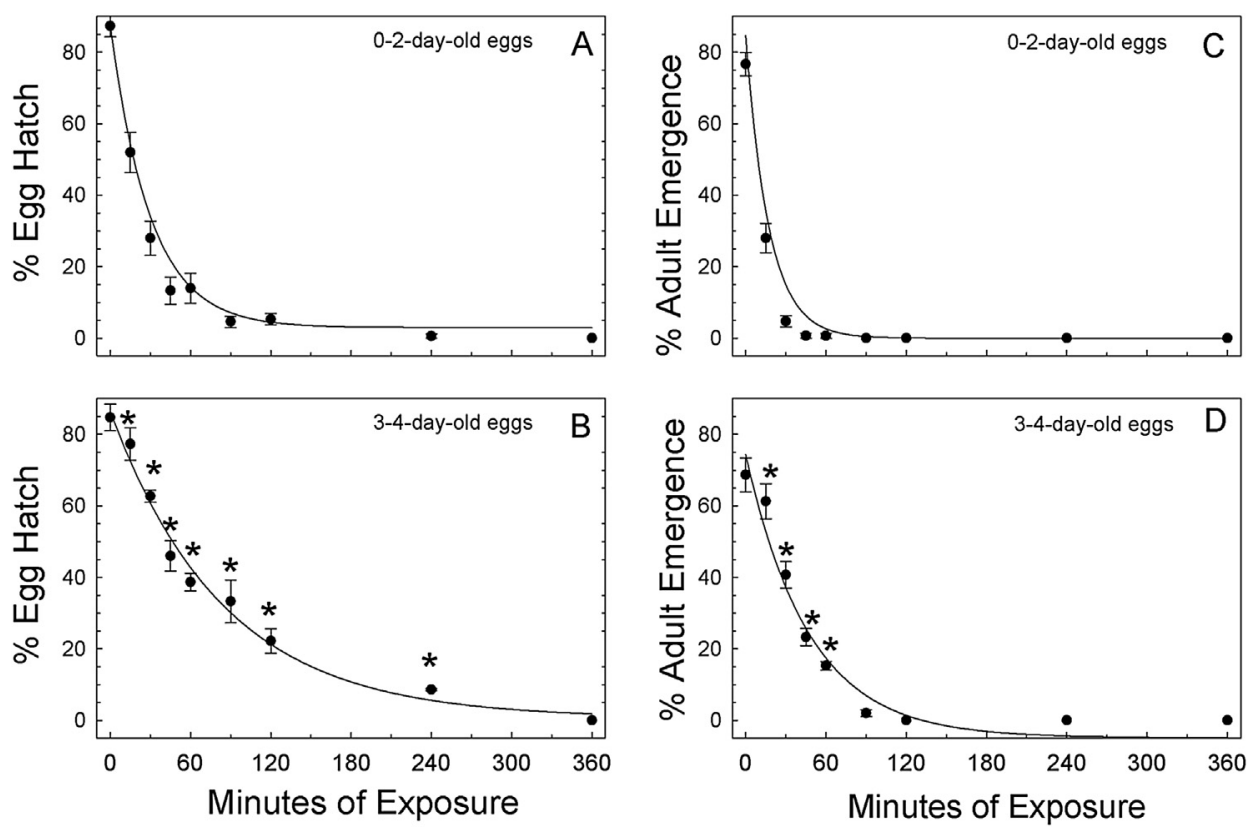

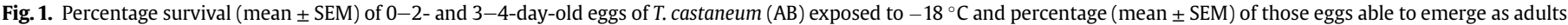

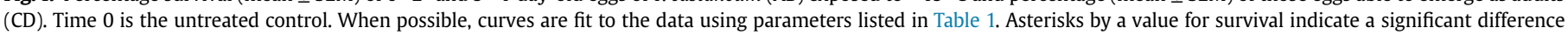
$(P<0.05)$ for that exposure time between the two age classes of eggs. 

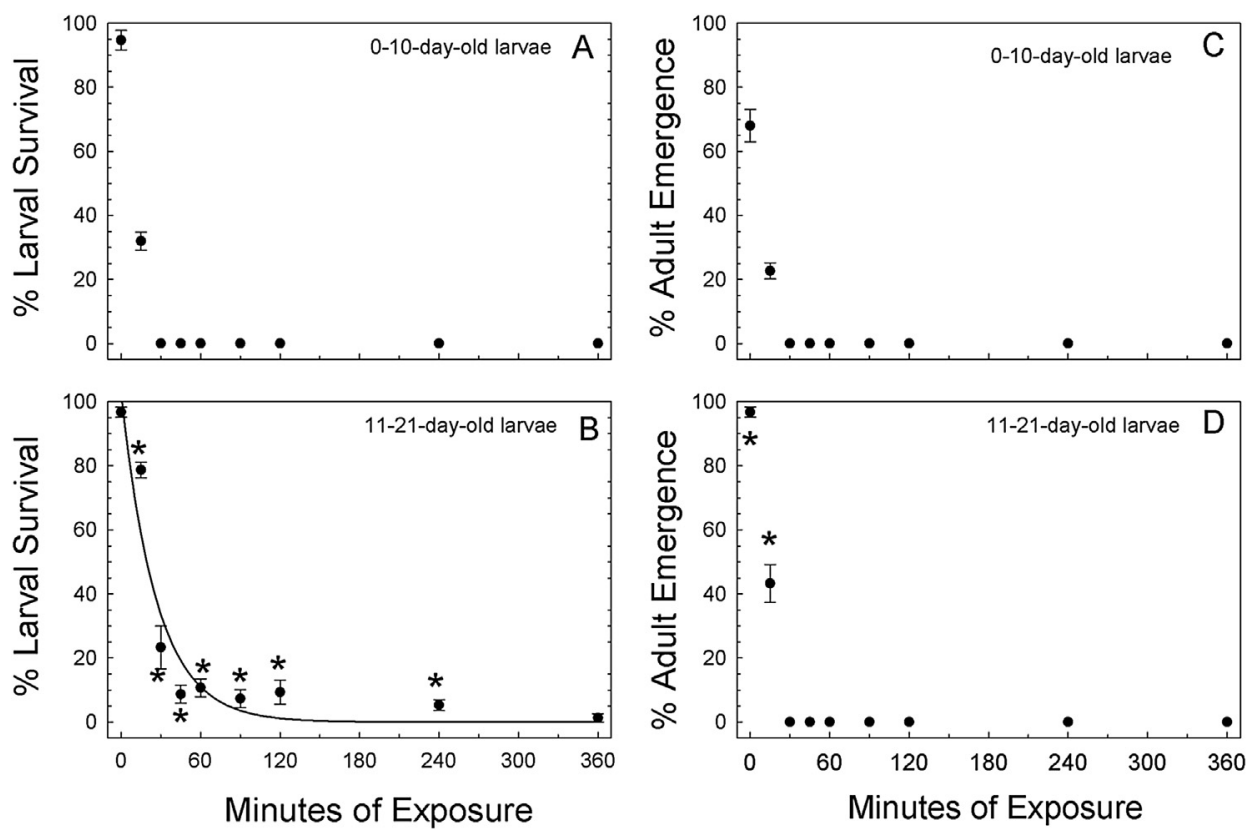

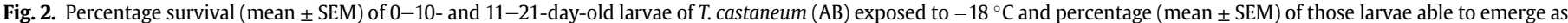

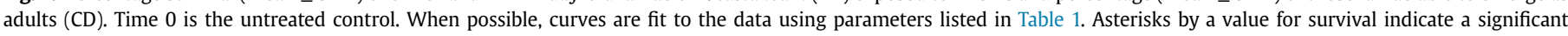
difference $(P<0.05)$ for that exposure time between the two age classes of larvae.

(Fig. 2B). However, for both larval age classes, none of the larvae exposed to $-18{ }^{\circ} \mathrm{C}$ for more than 15 min were able to emerge as adults (Fig. 2CD).

After one week nearly all pupae in untreated controls had emerged, regardless of age class, therefore the only measure assessed was adult emergence after $15 \mathrm{~min}$ of exposure to $-18{ }^{\circ} \mathrm{C}$, which was $2.2 \pm 2.2 \%$ and $1.3 \pm 1.3 \%$ for 0 -4-day-old and $5-8$-dayold pupae, respectively (Fig. $3 \mathrm{AB}$ ). There was no survival at any exposure time beyond $15 \mathrm{~min}$. Similarly, we report data only for the mortality assessment that was made for adults after 21 days.
Survival of 0-7-day-old and 21-28-day-old adults after $15 \mathrm{~min}$ of exposure to $-18{ }^{\circ} \mathrm{C}$ was low, only $2.0 \pm 2.0$ and $1.3 \pm 1.3 \%$, respectively (Fig. 3CD).

Data were also examined by determining the first exposure interval in our study that produced $100 \%$ mortality or $100 \%$ inhibition of adult emergence (Fig. 4). Minutes were converted to hours for ease of comparison between initial mortality of immature stages and adult emergence, and also eventual comparison to data for $T$. inclusum. The final assessments were done at $2,4,6$, and $8 \mathrm{~h}$, so the effects could have occurred earlier than what is listed because of
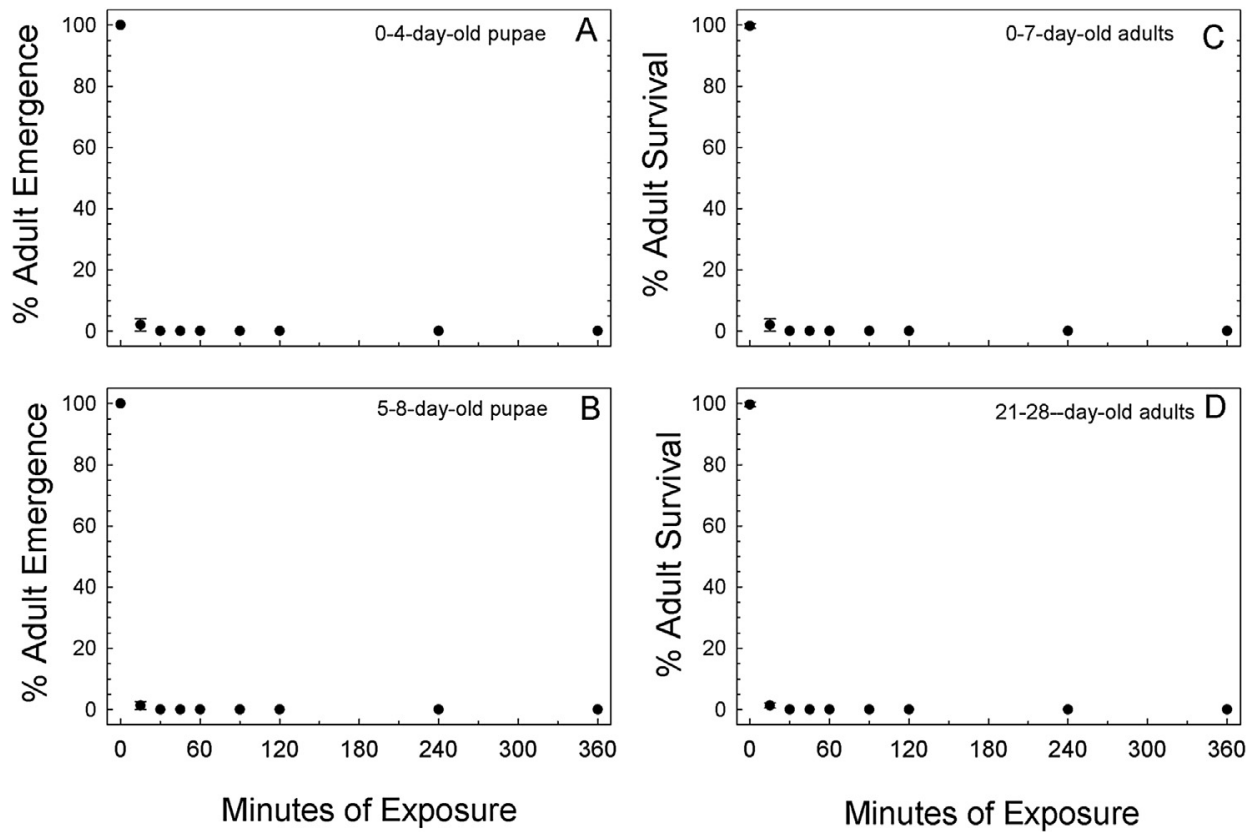

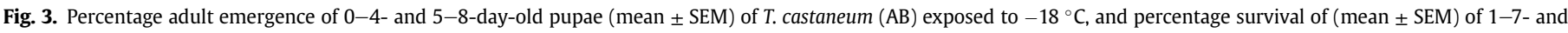
$21-28$-day-old adults $(\mathrm{CD})$. Time 0 is the untreated control. 


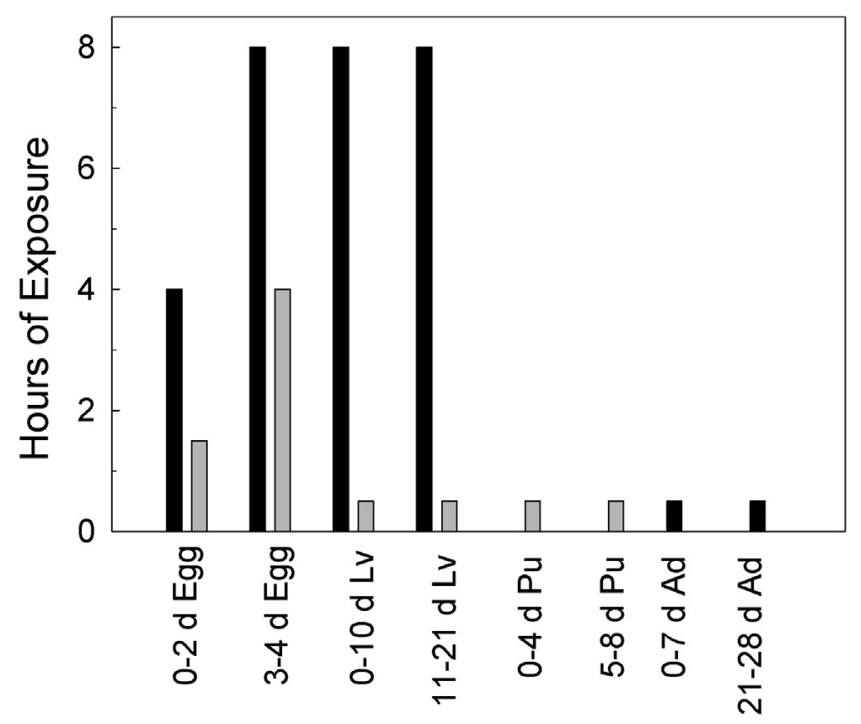

Fig. 4. First exposure time interval where no survival of an individual life stage of $T$. castaneum occurred (black bar) and the first time interval that produced no adult emergence of the exposed life stage (grey bar). No time is shown for survival of pupae, and only survival is shown for adults. Lv, larvae; $\mathrm{Pu}$, pupae; and Ad, adults.

the gap between the assessment times. Although the young larvae were one of the most tolerant stages at the initial one-week mortality assessments, these larvae for the most part did not emerge as adults (Fig. 4). Similarly, none of the eggs survived by the 8 -hr exposures, but the older eggs clearly were the most tolerant stage as they required $4 \mathrm{~h}$ of exposure to $-18^{\circ} \mathrm{C}$ for complete inhibition of adult emergence (Fig. 4).

\subsection{T. inclusum}

The main effects life stage and exposure time, and their interaction, were significant at $P<0.01$ for both the initial survival after one week $(\mathrm{F}=36.8, \mathrm{df}=7,355 ; \mathrm{F}=358.6, \mathrm{df}=21,355$; and $\mathrm{F}=16.4$, $\mathrm{df}=42,355$, respectively), and also for eventual adult emergence of immatures $(\mathrm{F}=82.5, \mathrm{df}=7,355 ; \mathrm{F}=138.7, \mathrm{df}=21,355$; and $\mathrm{F}=29.3, \mathrm{df}=42,355$, respectively). Data for individual life stages were analyzed as was done for $T$. castaneum by fitting curves to the data (Table 2), and similar to T. castaneum, initial survival and adult emergence decreased exponentially as exposure time increased. However, the exposure times for the different life stages of $T$. inclusum were analyzed in hours rather than minutes as was done for $T$. castaneum. When possible, significant differences within a particular life stage and exposure interval were also determined $(t-$ test, $P<0.05$ ). However, in most cases this could not be done because of the time differences between initial survival and inhibition of adult emergence. In some cases curves could not be fit to the data because values were essentially 0 beyond the first exposure period.

Survival of 0-2-day-old and 3-4-day-old eggs of T. inclusum was about $50 \%$ for up to $4 \mathrm{~h}$ of exposure to $-18{ }^{\circ} \mathrm{C}$, and did not drop below $20 \%$ until the 8 -and 10 -h exposure intervals (Fig. $5 \mathrm{AB}$ ). In contrast, the older egg stage of 5-6 days was much more susceptible compared to the other age classes. Survival was nearly $0 \%$ after only two hours of exposure, and survival of 5-6-day-old eggs was lower compared to the other two age classes for all exposure intervals up to $8 \mathrm{~h}$ (Fig. 5C). Adult emergence was only about $20 \%$ in the untreated controls, possibly due to larval cannibalism (Fig. 5DEF). Emergence was less than 10\% in eggs exposed for $2 \mathrm{~h}$, between 0 and $3 \%$ for exposures of 4 and $6 \mathrm{~h}$, and 0 at all other times (Fig. 5DEF).

Survival of $0-14$-day-old larvae declined from $88 \%$ after 15 min exposure to $33 \%$ after $30 \mathrm{~min}$, and ranged from 0 to $2.7 \%$ after one hour (Fig. 6A). In contrast, the 15-28-day-old larvae were much more tolerant to exposure at $-18{ }^{\circ} \mathrm{C}$, and survival did not drop below $20 \%$ until after $32 \mathrm{~h}$ of exposure (Fig. 6B). Adult emergence of unexposed control 0-14-day-old larvae was $46.7 \pm 8.5 \%$ compared to $89.0 \pm 2.4 \%$ for the older larvae, presumably because there were less effects of cannibalism with the older larvae. Even with the high survival of 15-28-day-old larvae, there was little adult emergence of exposed larvae of either age class (Fig. 6CD). Adult emergence of the one age class of exposed pupae declined quickly from 15 to $60 \mathrm{~min}$, with little survival occurring at 60 or more minutes of exposure (Fig. 7A). The 0 -4-day old adults were more tolerant to exposure at $-18^{\circ} \mathrm{C}$ compared to the 5-8-day old adults (Fig. 7BC).

Data were also examined by determining the first exposure interval in our study that produced $100 \%$ mortality or $100 \%$ inhibition of adult emergence of $T$. inclusum, as was done for T. castaneum. Older larvae of $T$. inclusum were the most tolerant life stage, requiring $64 \mathrm{~h}$ of exposure to $-18{ }^{\circ} \mathrm{C}$ for $100 \%$ mortality and $16 \mathrm{~h}$ of exposure for $100 \%$ inhibition of adult emergence (Fig. 8). As was the case with $T$. castaneum, mortality could have occurred earlier than what is listed because of the gap between the assessment times. However, it is clear much longer times were required for complete mortality and complete adult suppression of the immature stages of $T$. inclusum compared to $T$. castaneum.

\section{Discussion}

There are a number of previous studies which review and discuss high temperature and its effects on stored product insects (Fields, 1992; Abdelghany et al., 2010; Fields et al., 2012), and there is considerable variation in the susceptibility of individual life stages to extreme heat. The egg of the cigarette beetle Lasioderma

Table 2

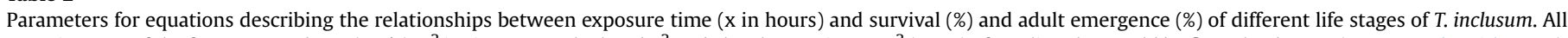

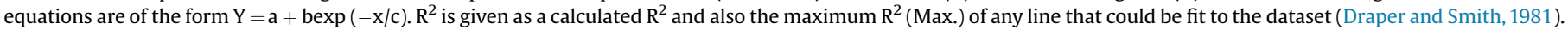
Equations could not be determined for life stages not listed because survival was at or near 0 by the 30-min exposure interval.

\begin{tabular}{|c|c|c|c|c|c|}
\hline Life stage & $\mathrm{a}$ & $\mathrm{b}$ & c & $\mathrm{R}^{2}$ & Max. $\mathrm{R}^{2}$ \\
\hline \multicolumn{6}{|c|}{ Initial survival after one week } \\
\hline 0-2-day-old egg & $-29.14 \pm 17.0$ & $101.12 \pm 15.4$ & $10.40 \pm 3.1$ & 0.84 & 0.89 \\
\hline 3-4-day-old egg & $-12.67 \pm 7.8$ & $89.94 \pm 7.3$ & $7.08 \pm 1.5$ & 0.84 & 0.87 \\
\hline 0-14-day-old larvae & $-2.42 \pm 2.5$ & $107.90 \pm 5.3$ & $0.48 \pm 0.1$ & 0.88 & 0.96 \\
\hline 15-28-day-old larvae & $-4.08 \pm 3.9$ & $96.08 \pm 4.5$ & $22.72 \pm 2.8$ & 0.90 & 0.92 \\
\hline 0-4-day-old adults & $-1.60 \pm 2.7$ & $100.28 \pm 4.5$ & $4.81 \pm 0.6$ & 0.93 & 0.93 \\
\hline \multicolumn{6}{|l|}{ Adult emergence } \\
\hline 0-2-day-old egg & $0.09 \pm 1.5$ & $24.50 \pm 3.7$ & $1.61 \pm 0.7$ & 0.87 & 0.87 \\
\hline 3-4-day-old egg & $-0.16 \pm 1.1$ & $26.89 \pm 2.6$ & $1.86 \pm 0.4$ & 0.69 & 0.69 \\
\hline pupae & $-3.50 \pm 2.3$ & $112.26 \pm 4.8$ & $0.49 \pm 0.1$ & 0.90 & 0.99 \\
\hline
\end{tabular}



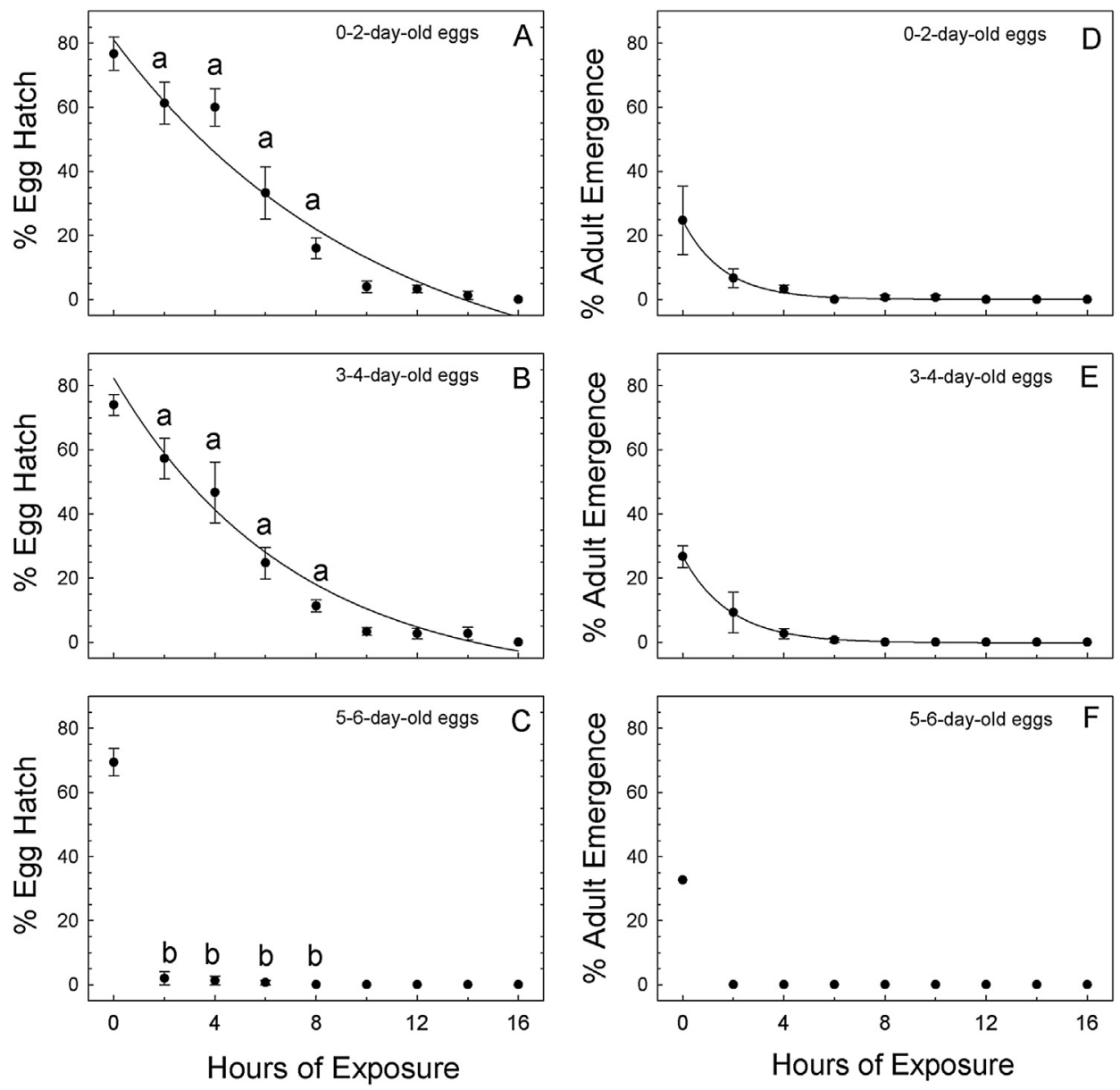

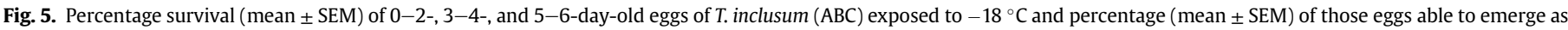

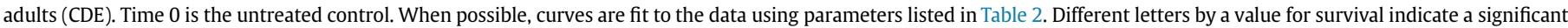
difference $(P<0.05)$ for that exposure time between the three age classes of eggs.
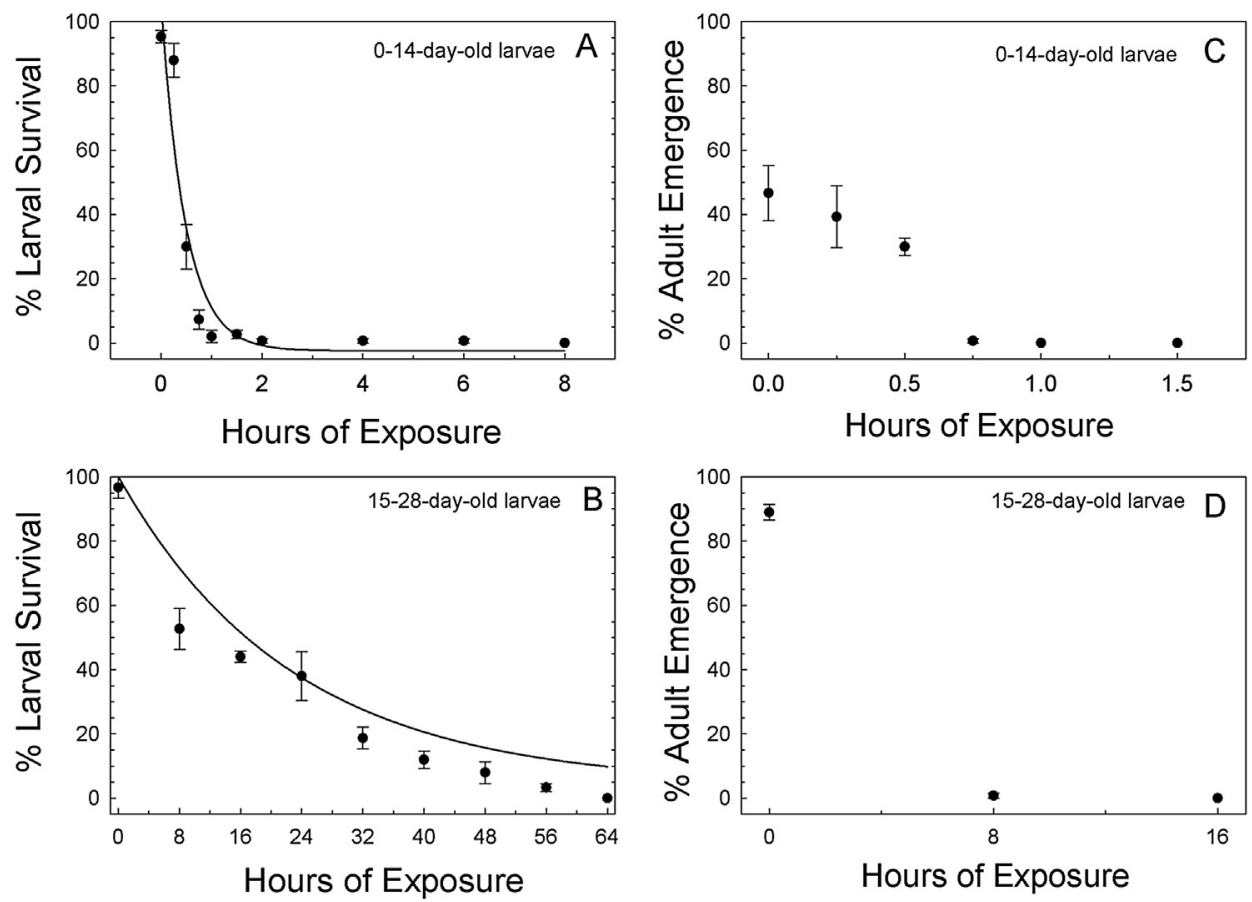

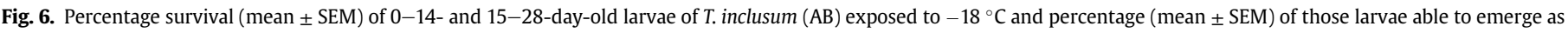
adults (CD). Time 0 is the untreated control. When possible, curves are fit to the data using parameters listed in Table 2. 
serricorne (Fab.) was the most tolerant life stage (Yu et al., 2011), while the most tolerant life stages of Tribolium confusum (Jacqueline DuVal), the confused flour beetle, and T. castaneum were old larvae (Boina and Subramanyam, 2004) and young larvae (Mahroof et al., 2003a,b), respectively. Fields (1992) summarizes various studies regarding effects of high temperatures on different stored product beetles and life stages.

A synthesis of the available literature of the Fields (1992) review indicated that eggs of beetle species were the life stage most susceptible to cold temperatures. The recent study by Abdelghany et al. (2010) stated that eggs of Stegobium paniceum (L.), the drugstore beetle, were the most susceptible life stage to $0{ }^{\circ} \mathrm{C}$. They also summarized literature supporting the view that generally adults of stored product beetle species were the least susceptible life stage to cold temperatures. In studies with stored product moths, the egg was the most tolerant life stage (Fields, 1992; Abdelghany et al., 2010; Limonta and Locatelli, 2015). Many of the studies cited in the reviews by Fields (1992) and Abdelghany et al. (2010) were focused on developmental studies at low temperatures, and not on using low temperatures as a potential disinfestation strategy; consequently the lowest temperatures used in those studies was rarely lower that $0{ }^{\circ} \mathrm{C}$.

Johnson and Valero (2003) investigated use of commercial freezers set at $-18{ }^{\circ} \mathrm{C}$ to control cowpea weevils, Callosobruchus maculatus, in garbanzo beans. They found that the egg was the most tolerant stage, while adults were least tolerant. Similarly, Eaton and Kells (2011) reported the eggs of the mold mite, Tyrophagus putrescentiae, were most tolerant to cold, while nymphs and adults were less tolerant. Control of $90 \%$ of all stages of the mites could be achieved in $5 \mathrm{~h}$ at $-18{ }^{\circ} \mathrm{C}$. Eliopoulos et al. (2011) reported that almost all stages of Oryzaephilus surinamensis, T. confusum, and Trogoderma granarium were dead after $4 \mathrm{~h}$ of exposure to $-16^{\circ} \mathrm{C}$. $O$. surinamensis larvae were dead after $8 \mathrm{~h}$, while older T. granarium larvae and adults required 48 and $24 \mathrm{~h}$, respectively, for complete mortality. Results from our study for T. inclusum in the same genus were similar to that of Eliopoulos et al. (2011).

In our study we assessed susceptibility of $T$. castaneum and $T$. inclusum by examining egg hatch, larval mortality, or adult mortality one week after exposure at various time intervals to $-18^{\circ} \mathrm{C}$, and by assessing eventual adult emergence of exposed eggs, larvae, and pupae. In general, the time for exposure that was required to completely inhibit adult emergence of immatures was much lower than the time required for direct mortality of those immatures. Older eggs and larvae of both species were the most tolerant stages in relation to direct mortality, while eggs of $T$. castaneum and 15-28-day-old larvae of $T$. inclusum were the most tolerant stages using the measure of eventual adult emergence. Larval survival of $T$. inclusum occurred out to $64 \mathrm{~h}$, but a 16-h exposure completely inhibited adult emergence. Eight and $64 \mathrm{~h}$ of exposure to $-18{ }^{\circ} \mathrm{C}$ is required to kill all stages of $T$. castaneum and Trogoderma inclusum, respectively, while 4 and $16 \mathrm{~h}$, respectively, of exposure to $-18{ }^{\circ} \mathrm{C}$ is required to prevent development to the adult stage of both species from immature stages. The larvae appeared to be arrested in that stage, similar to exposure to an insect growth regulator. Also, adults of both species were generally the most susceptible stage, not the most tolerant as has been reported for most studies. The fact that we used two measures to assess susceptibility and used a temperature far lower than what was used for most studies could account for our discrepant results.

Our study also indicated variation in egg susceptibility to $-18^{\circ} \mathrm{C}$ with age. The 3-4-day-old eggs of T. castaneum were more tolerant than the 0-2-day-old eggs, while the 5-6-day-old eggs of T. inclusum were much more susceptible than the 0-2- and 3-4-day-old eggs. The neonates of $T$. inclusum were plainly visible in the 5-6day-old eggs, indicating that differences in development between the two species may play a role in conferring susceptibility. Recent studies by Kharel et al. (2014a,b) showed that eggs of $T$. castaneum and $T$. confusum were the life stage most susceptible to pyrethrin aerosol. Many previous studies have shown that the egg stage of stored product insects is generally the most tolerant life stage to fumigants (Hartzer et al., 2010; Tsai et al., 2011; Phillips et al., 2012).

In our study, eggs of $T$. inclusum were much more tolerant to $-18{ }^{\circ} \mathrm{C}$ than eggs and larvae of $T$. castaneum. The difference in
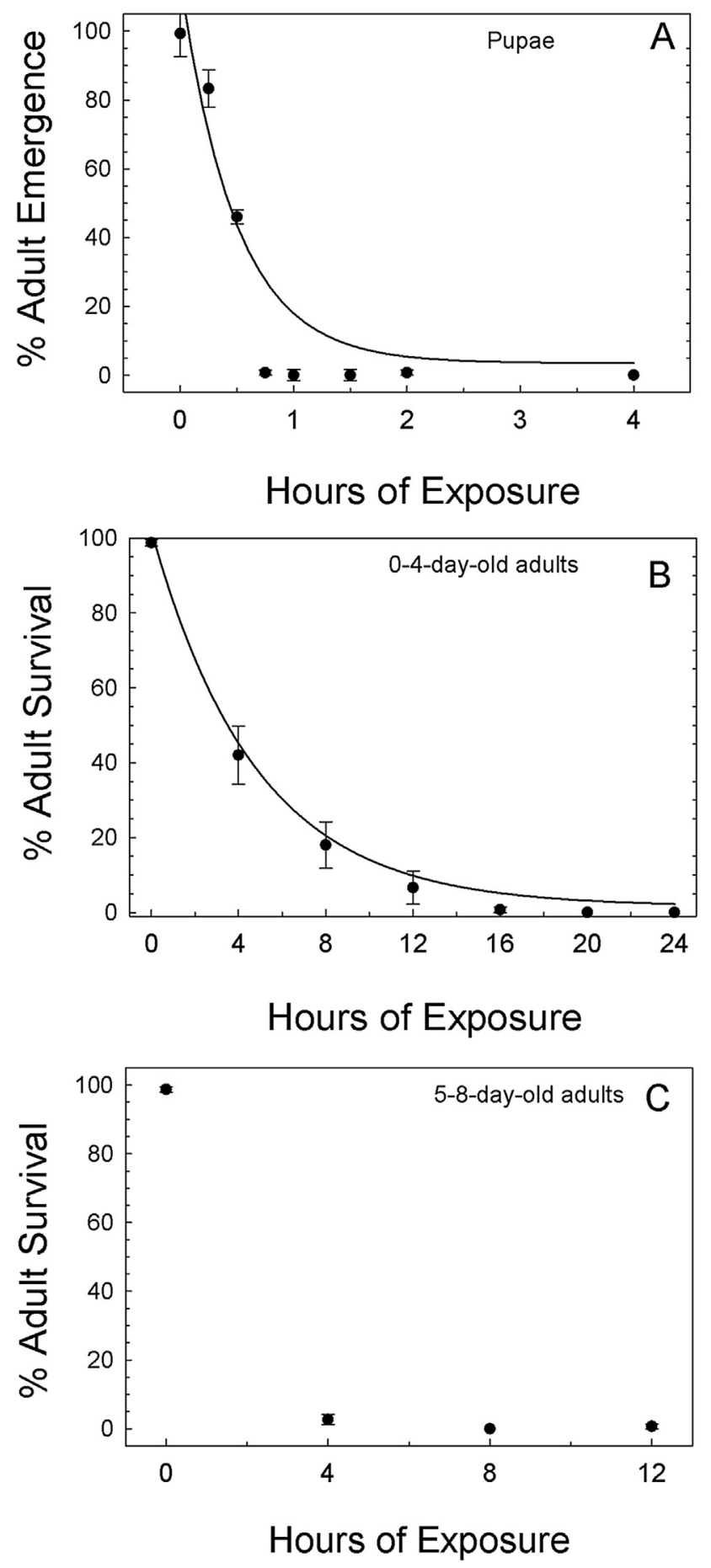

Fig. 7. Percentage adult emergence of pupae (mean \pm SEM) of $T$. inclusum (A) exposed to $-18{ }^{\circ} \mathrm{C}$ and percentage survival of (mean \pm SEM) of $0-4$ - and 5-8-day-old adults (BC). Time 0 is the untreated control. When possible, curves are fit to the data using parameters listed in Table 2. 


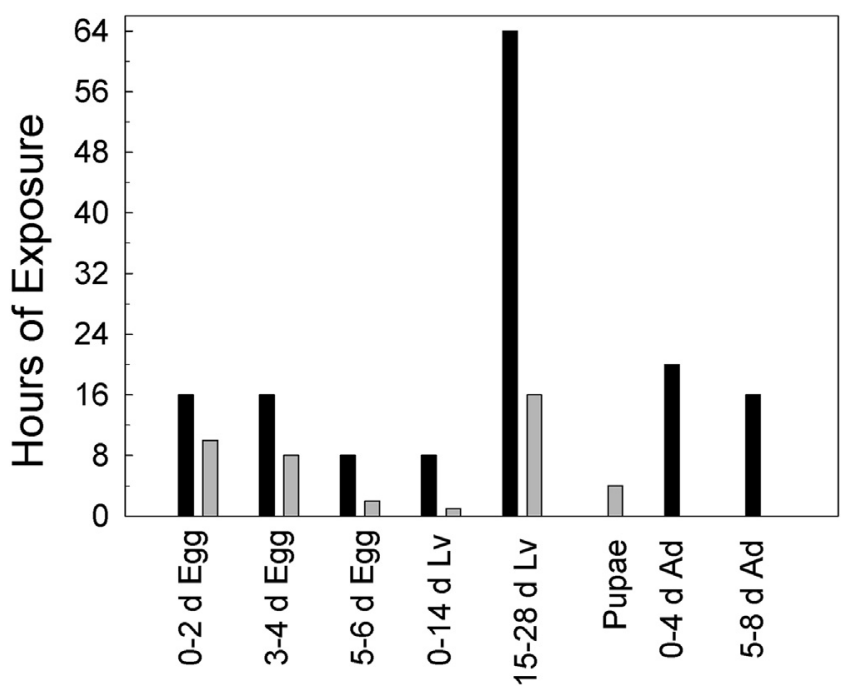

Fig. 8. First exposure time interval where no survival of an individual life stage of $T$. inclusum occurred (black bar) and the first time interval that produced no adult emergence of the exposed life stage (grey bar). No time is shown for survival of pupae and only survival is shown for adults. Lv, larvae; Pu, pupae; and Ad, adults.

susceptibility of eggs may relate to the physical structure of the eggs, including aeropyles and micropiles, respiratory openings on the chorion (Gautam et al., 2014, 2015) which could provide gas and air exchange into the egg. The thickness of the chorion may also be a factor in diffusion of cold into the egg. Gautam et al. (2015) state that the types of layers and relative thicknesses of different layers of the chorion also vary across insect species. Hence, differences in susceptibility of eggs of $T$. castaneum and T. inclusum may relate to these differences in egg structure, but further confirmatory research is needed.

These studies were conducted with only one strain of each insect species. The $T$. castaneum strain was a field-collected strain that had been in culture since 2005, while the T. inclusum strain was collected from the field in 2012 and cultured in the lab since that time. There are studies that show field strains of stored product beetles can vary in their susceptibility to insecticides, and may be more tolerant than pesticide-susceptible strains that have been reared for long time periods in the laboratory (Sehgal et al., 2013, 2014). Thus, while our results can be used as general guidelines for susceptibility of different life stages of $T$. castaneum and $T$. inclusum and to compare relative susceptibility of the two species, field strains exist in fluctuating temperatures and may show susceptibility different from our results. Acclimation of stored product insects to cold temperatures will affect susceptibility (Fields, 1992; Fields et al., 2012), therefore longer exposure times may be needed under field conditions to achieve the same results. However, commercial use of freezers to disinfest stored products would occur mainly during the summer when insect infestations are most severe, so acclimation would not be an issue. We did not include food in our treatment vials because we wanted to determine the time required to kill insects using freezing independent of the commodity infested. Thus, our results are applicable to any commodity by measuring temperature in the commodity until $-18{ }^{\circ} \mathrm{C}$ is reached or by using models that predict cooling temperatures of commodities (e.g., Mascheroni and Calvelo, 1982; Flinn et al., 2015).

\section{Acknowledgments}

We thank Ken Friesen for excellent technical assistance throughout this study. This paper reports the results of research only. Mention of trade names or commercial products in this publication is solely for the purpose of providing specific information and does not imply recommendation or endorsement by the U.S. Department of Agriculture. The US Department of Agriculture is an equal opportunity provider and employer.

\section{References}

Abdelghany, A.Y, Awadalla, S.S., Abdel-Bakye, N.F., El-Syrafi, H.A., Fields, P.G, 2010. Effect of high and low temperatures on the drugstore beetle (Coleoptera: Anobiidae). J. Econ. Entomol. 103, 1909-1914.

Beal Jr., R.S., 1954. Biology and Taxonomy of the Nearctic Species of Trogoderma. In: University of California Miscellaneous Publications in Entomology, vol. 10, pp. 35-102.

Boina, D., Subramanyam, B., 2004. Relative susceptibility of Tribolium confusum life stages exposed to elevated temperatures. J. Econ. Entomol. 97, 2168-2173.

Draper, N., Smith, H., 1981. Applied Regression Analysis. John Wiley \& Sons, New York.

Eaton, M., Kells, S.A., 2011. Freeze mortality characteristics of the mold mite Tyrophagus putrescentiae, a significant pest of stored products. J. Econ. Entomol. 104 1423-1429.

Eliopoulos, P.A., Prasodimou, G.Z., Pouliou, A.V., 2011. Time-mortality relationships of larvae and adults of grain beetles exposed to extreme cold. Crop Prot. 30, 1097-1102.

Fields, P.G., 1992. The control of stored-product insects and mites with extreme temperatures. J. Stored Prod. Res. 28, 89-118.

Fields, P.G., White, N.D.G., 2002. Alternatives to methyl bromide treatments for stored-product and quarantine insects. Annu. Rev. Entomol. 47, 331-359.

Fields, P.G., Subramanyam, B., Hulasare, R., 2012. Extreme temperatures. In: Hagstrum, D.W., Phillips, T.W., Cuperus, G. (Eds.), Stored Products. Kansas State University Agricultural Experiment Station and Cooperative Extension Service, pp. 179-190. http://www.ksre.ksu.edu/bookstore/pubs/S156.pdf (accessed 05.03.15.).

Flinn, P.W., Arthur, F.H., Throne, J.E., Friesen, K.H., Hartzer, K.L., 2015. Cold temperature disinfestation of bagged flour. J. Stored Prod. Res. 63, 42-46.

Gautam, S.G., Opit, G.P., Margosan, D., Tebbets, J.S., Walse, S., 2014. Egg morphology of key stored-product insect pests of the United States. Ann. Entomol. Soc. Am. 107, 1-10.

Gautam, S.G., Opit, G.P., Margosan, D., Hoffman, D., Tebbets, J.S., Walse, S., 2015. Comparative egg morphology and chorionic ultrastructure of key storedproduct insect pests. Ann. Entomol. Soc. Am. 108, 43-56.

Hagstrum, D.W., 1987. Seasonal variation of stored wheat environment and insect populations. J. Econ. Entomol. 16, 77-83.

Hartzer, M., Subramanyam, B., Chayaprasert, W., Maier, D.E., Savoldelli, S., Campbell, J.F., Flinn, P.W., 2010. Methyl bromide and sulfuryl fluoride effectiveness against red flour beetle life stages. In: Carvalho, M.O., et al. (Eds.), Proceedings of the 10th International Working Conference on Stored Product Protection, vol. 425. Julius-Kühn-Archiv, Estoril, Portugal, pp. 365-370.

Howe, R.W., 1962. The effects of temperature and humidity on the oviposition rate of Tribolium castaneum (Hbst.) (Coleoptera: Tenebrionidae). Bull. Entomol. Res. 53, 301-310.

Howe, R.W., 1965. A summary of optimal and minimal conditions for population increase of some stored products insects. J. Stored Prod. Res. 1, 177-184.

Johnson, J.A., Valero, K.A., 2003. Use of commercial freezers to control cowpea weevil, Callosobruchus maculatus (Coleoptera: bruchidae), in organic garbanzo beans. J. Econ. Entomol. 96, 1952-1957.

Kharel, K., Arthur, F.H., Zhu, K.Y., Campbell, J.F., 2014a. Evaluation of synergized pyrethrin aerosol for control of Tribolium castaneum and Tribolium confusum (Coleoptera: Tenebrionidae). J. Econ. Entomol. 107, 462-468.

Kharel, K., Arthur, F.H., Zhu, K.Y., Campbell, J.F., 2014b. Susceptibility of different life stages of Tribolium confusum to pyrethrin aerosol: effects of a flour food source on insecticidal efficacy. J. Pest Sci. 87, 295-300.

Limonta, L., Locatelli, D.P., 2015. Susceptibility of eggs of Idaea inquinata (Scop.) (Lepidoptera, Geometridae) to high and low temperatures. J. Stored Prod. Res. $60,1-4$.

Loschiavo, S.R., 1960. Life-history and behaviour of Trogoderma parabile Beal (Coleoptera: Dermestidae). Can. Entomol. 92, 611-618.

Loschiavo, S.R., 1967. Adult longevity and oviposition of Trogoderma parabile Beal (Coleoptera, Dermestidae) at different temperatures. J. Stored Prod. Res. 3, 273-282.

Mahroof, R., Subramanyam, B., Throne, J., Menon, A., 2003a. Time-mortality relationships for Tribolium castaneum (Herbst) life stages exposed to elevated temperatures. J. Econ. Entomol. 96, 1345-1351.

Mahroof, R., Subramanyam, B., Eustace, D., 2003b. Temperature and relative humidity profiles during heat treatment of mills and its efficacy against Tribolium castaneum (Herbst) life stages. J. Stored Prod. Res. 39, 555-569.

Mascheroni, R.H., Calvelo, A., 1982. A simplified model for freezing time calculations in foods. J. Food Sci. 47, 1201-1207.

Mullen, M.A., Arbogast, R.T., 1988. Insect succession in a stored-corn ecosystem in southeast Georgia. J. Econ. Entomol. 81, 899-912.

Partida, G.J., Strong, R.G., 1970. Distribution and relative abundance of Trogoderma spp. in relation to climate zones of California. J. Econ. Entomol. 63, 1553-1560. 
Partida, G.J., Strong, R.J., 1975. Comparative studies on the biologies of six species of Trogoderma: T. inclusum. Ann. Entomol. Soc. Am. 68, 91-103.

Phillips, T.W., Thoms, E.M., DeMark, J., Walse, S., 2012. Fumigation. In: Hagstrum, D.W., Phillips, T.W., Cuperus, G. (Eds.), Stored Products. Kansas State University Agricultural Experiment Station and Cooperative Extension Service, pp. 157-179 (accessed 30.06.15.). http://www.ksre.ksu.edu/bookstore/pubs/ S156.pdf.

Rees, D., 2004. Insects of Stored Products. CSIRO Publishing, Collingwood, VIC, Australia, p. 181.

Sehgal, B., Subramanyam, B., Arthur, F., Gill, B.S., 2013. Variation in susceptibility of field strains of three stored grain insect species to spinosad and chlorpyrifosmethyl plus deltamethrin on hard red winter wheat. J. Econ. Entomol. 106, 1911-1919.

Sehgal, B., Subramanyam, B., Arthur, F., Gill, B.S., 2014. Variation in susceptibility of laboratory and field strains of three stored-grain insect species to $\beta$-cyfluthrin and chlorpyrifos-methyl plus deltamethrin applied to concrete surfaces. Pest Manag. Sci. 70, 576-587.
Tsai, W.T., Mason, L.J., Chayaprasert, W., Maier, D.E., Ileleji, K.E., 2011. Investigation of fumigant efficacy in flour mills under real-world fumigation conditions. J. Stored Prod. Res. 179-184.

Vick, K.W., 1973. Effects of interspecific matings of Trogoderma glabrum and T. inclusum on oviposition and re-mating. Ann. Entomol. Soc. Am. 66, 237-239.

Vick, K.W., Drummond, P.C., Coffelt, J.A., 1973. Trogoderma inclusum and T. glabrum: effects of time of day on production of female pheromone, male responsiveness, and mating. Ann. Entomol. Soc. Am. 66, 1001-1004.

White, G.G. 1987. Effects of temperature and humidity on the rust-red flour beetle Tribolium castaneum (Coleoptera: Tenebrionidae), in wheat grain. Aust. J. Zool. 35, 43-59.

Wright, E.J., Sinclair, E.A., Annis, P.C., 2002. Laboratory determination of the requirements for control of Trogoderma variabile (Coleoptera: Dermestidae) by heat. J. Stored Prod. Res. 38, 147-155.

Yu, C., Subramanyam, B., Flinn, P.W., Gwirtz, J.A., 2011. Susceptibility of Lasioderma serricorne (Coleoptera: Anobiidae) life stages to elevated temperatures used during structural heat treatments. J. Econ. Entomol. 104, 317-324. 